IRA-International Journal of Applied Sciences ISSN 2455-4499; Vol.04, Issue 02 (2016)

Institute of Research Advances

Pg. no. 315-318

http://research-advances.org/index.php/IRAJAS

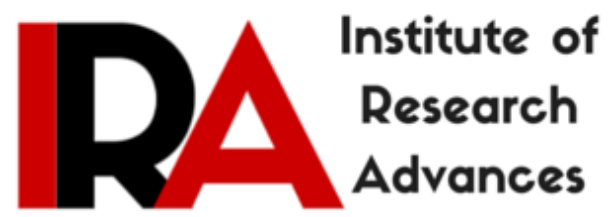

\title{
Preliminary secondary metabolites detection of aqueous extracts obtained from different tissues of in-vitro originated Eclipta alba
}

Pushpa Dodake ${ }^{1}$, Malika Pal ${ }^{2}$

${ }^{1}$ Dept. of Botany and Biotechnology, Sadhu Vaswani College, Bhopal.

2 Principal SAM Girls College, Bhopal.

Type of Review: Peer Reviewed.

DOI: http://dx.doi.org/10.21013/jas.v4.n2.p12

\section{How to cite this paper:}

Dodake, P., \& Pal, M. (2016). Preliminary secondary metabolites detection of aqueous extracts obtained from different tissues of in-vitro originated Eclipta alba. IRAInternational Journal of Applied Sciences, 4(2), 315-318. doi:http://dx.doi.org/10.21013/jas.v4.n2.p12

(C) Institute of Research Advances

\section{(cc) EY-NC}

This work is licensed under a Creative Commons Attribution-Non Commercial 4.0 International License subject to proper citation to the publication source of the work.

Disclaimer: The scholarly papers as reviewed and published by the Institute of Research Advances (IRA) are the views and opinions of their respective authors and are not the views or opinions of the IRA. The IRA disclaims of any harm or loss caused due to the published content to any party. 


\section{ABSTRACT}

Eclipta alba is well known herbal plant for its vast range of pharmaceutically important properties. Some of its major activities are antimytotoxic, antimicrobial, antihepatotoxic, antioxidant, antihyperglycemic, rejuveniser and antivenom action. The present study reveals the presence of secondary metabolites responsible for imparting pharmacological properties in different parts like apical tissue, meristematic cells, whole plant, Callus, Seedlings, Mature seeds, immature seeds and dries seeds obtained via plant tissue culture technique. The results shows the absence of Alkaloids in tissue cultures plants which has been normally reported to be present in huge amounts in naturally occurring plants in aqueous extracts but other metabolites viz., Flavonoids, Tannins and phenolic groups reported earlier to be occurring in Eclipta alba and its parts were found to be present in aqueous extracts of tissue cultured plant.

Keywords: Eclipta alba, Phytochemicals, plant tissue culture, quantification

\section{Introduction}

Eclipta alba, commonly known as bhringraaj is very well known herbal plant in India especially due to its use as hair tonic. The vast range of secondary metabolites showing antimytotoxic, antimicrobial, antihepatotoxic, antioxidant, antihyperglycemic, rejuveniser and antivenom action etc. has been investigated and reported in Eclipta alba. The bioactive compounds responsible for these activities are alkaloids, flavonoids, Phenolic compouns, Tannins, Saponin etc. ${ }^{1}$ The world is moving towards use of herbal remedies for treatment due to less or negligible side effects associated with these drugs. The demand and commercialization of herbal drugs create over exploitation of already existing plants and also huge attraction of farmers to cultivate them on large scale. This is surely creating an agroecological imbalance ${ }^{2}$. Therefore the need of the day is to develop some protocols so that these plants can be generated in laboratories in large amount to fulfil the need and also maintain the balance in environment. As it is evident that after in vitro culture some variations are induced in plants and their metabolites so a study was made to interpret those variations so that the importance and implementation of tissue cultured Eclipta alba can be recognized more clearly.

\section{Material and Method}

The plants were raised by tissue culture technique. The air dried tissues were pulverized to fine particles and subjected to hot extraction using soxhlet apparatus. 100 gram of each tissue powder was extracted with distilled water at $80^{\circ} \mathrm{C}$. The extracts were collected and concentrated using water bath to obtain crude extracts and remove the solvent. The the extracts were used to determine the presence of useful secondary metabolites.

Phytochemical Testing: Chemical tests were carried out for different extract to detect the presence of bioactive components like Alkaloids, Carbohydrates, reducing sugars, Flavonoids, Glycosides, Tannin and Phenolic compounds, Saponin, Triterpenoids and Steroids in them by using standard methods of Kokate et al. ${ }^{3}$.

\section{Results}

The result clearly depicts the absence of Alkaloids in aqueous extracts of in-vitro generated tissues of Eclipta alba while it was present in the Mature and Immature seeds of natural origin. The carbohydrates were found to be present in mature seeds (Natural) and Callus (in-vitro). Reducing sugars, Glycosides, Triterpenoids and Steroids were absent in all the tissues. The flavonoids were present in immature seeds, apicals tissues, maristamatic tissues and whole plants. Tannins and Phenolic compounds were absent in mature seed, dried seeds, seedling plants whereas these metabolites were found to be present in immature seed, Apical tissues, maristamatic cells, whole plant and Callus. Saponin was present in dried seeds, apical meristem and seedling plants.

The results clearly shows the absence of Alkaloids in tissue cultures plants which has been normally reported to be present in huge amounts in naturally occurring plants in aqueous extracts but other 
metabolites viz., Flavonoids, Tannins and phenolic groups reported earlier to be occurring in Eclipta alba and its parts were found to be present in tissue cultured plants. ${ }^{4}$ Eclipta alba is highly important plant for its huge medicinal importance and is in great demand in herbal drug industry and among the people trusting its miraculous ayurvedic effects without any observable side effects. Recently large interests in natural medicines that are obtained from plant parts or plant extracts have been created worldwide. On the order of $40 \%$ or more of the pharmaceuticals currently used in Western countries are derived or at least partially derived from natural sources. ${ }^{5}$

Although the results are only based on the aqueous extracts so further analysis is required for clarifying the changes in secondary metabolite profile of tissue cultured Eclipta alba so that its proper and real value can be predicted for production and commercialization of tissue cultured plants to maintain the ecological balance and harmony being disturbed due to overexploitation of naturally occurring Eclipta elba.

\begin{tabular}{|c|c|c|c|c|c|c|c|c|c|}
\hline \multirow[b]{2}{*}{$\begin{array}{c}\text { S. } \\
\text { No }\end{array}$} & \multirow[b]{2}{*}{ Test } & \multicolumn{8}{|c|}{ Results } \\
\hline & & S1 & S2 & S3 & $\mathbf{P 1}$ & $\mathbf{P 2}$ & P3 & $\mathbf{P 4}$ & P5 \\
\hline \multicolumn{10}{|c|}{ Alkaloid } \\
\hline 1 & Mayer's Test & $+\mathrm{ve}$ & $+\mathrm{ve}$ & - ve & - ve & - ve & - ve & - ve & -ve \\
\hline 2 & Wagner's Test & $+\mathrm{ve}$ & $+\mathrm{ve}$ & -ve & -ve & -ve & -ve & -ve & -ve \\
\hline 3 & Hager's Test & $+\mathrm{ve}$ & $+\mathrm{ve}$ & -ve & -ve & -ve & -ve & -ve & -ve \\
\hline \multicolumn{10}{|c|}{ Carbohydrate } \\
\hline 1 & Molish's Test & $+\mathrm{ve}$ & -ve & +ve & -ve & -ve & -ve & $+\mathrm{ve}$ & -ve \\
\hline 2 & Barfoed's Test & $+\mathrm{ve}$ & -ve & $+\mathrm{ve}$ & -ve & -ve & -ve & $+\mathrm{ve}$ & -ve \\
\hline \multicolumn{10}{|c|}{ Reducing Sugars } \\
\hline 1 & Fehling's Test & -ve & -ve & -ve & -ve & -ve & -ve & -ve & -ve \\
\hline 2 & Benedict's Test & -ve & -ve & -ve & -ve & -ve & -ve & -ve & -ve \\
\hline \multicolumn{10}{|c|}{ Flavonoids } \\
\hline 1 & Alkaline reagent Test & -ve & $+\mathrm{ve}$ & -ve & $+v e$ & $+\mathrm{ve}$ & $+\mathrm{ve}$ & -ve & -ve \\
\hline 2 & Shinoda Test & -ve & $+\mathrm{ve}$ & -ve & + ve & $+\mathrm{ve}$ & $+\mathrm{ve}$ & -ve & -ve \\
\hline 3 & Lead Acetate Test & -ve & $+\mathrm{ve}$ & -ve & $+\mathrm{ve}$ & $+\mathrm{ve}$ & $+\mathrm{ve}$ & -ve & -ve \\
\hline \multicolumn{10}{|c|}{ Glycoside } \\
\hline 1 & Borntrager's Test & -ve & -ve & -ve & $-\mathrm{ve}$ & -ve & -ve & -ve & -ve \\
\hline 2 & Legal's Test & -ve & -ve & -ve & $-\mathrm{ve}$ & -ve & -ve & -ve & -ve \\
\hline 3 & Killer-Killiani Test & -ve & -ve & -ve & -ve & -ve & -ve & -ve & -ve \\
\hline \multicolumn{10}{|c|}{ Tannin and Phenolic Compounds } \\
\hline 1 & Ferric Chloride Test & -ve & $+\mathrm{ve}$ & -ve & $+v e$ & $+\mathrm{ve}$ & + ve & $+\mathrm{ve}$ & -ve \\
\hline 2 & Lead Acetate Test & -ve & $+\mathrm{ve}$ & -ve & $+v e$ & $+\mathrm{ve}$ & $+\mathrm{ve}$ & $+\mathrm{ve}$ & -ve \\
\hline 3 & Dilute Iodine Test & -ve & $+\mathrm{ve}$ & -ve & $+v e$ & $+\mathrm{ve}$ & $+\mathrm{ve}$ & $+\mathrm{ve}$ & -ve \\
\hline
\end{tabular}




\begin{tabular}{|c|c|c|c|c|c|c|c|c|c|}
\hline \multicolumn{10}{|c|}{ Saponins } \\
\hline 1 & Foam Test & $-\mathrm{ve}$ & $-v e$ & $+\mathrm{ve}$ & $+\mathrm{ve}$ & $-\mathrm{ve}$ & -ve & $-\mathrm{ve}$ & $+\mathrm{ve}$ \\
\hline \multicolumn{10}{|c|}{ Triterpenoids and steroids } \\
\hline $\mathbf{1}$ & Salwonski Test & $-\mathrm{ve}$ & $-\mathrm{ve}$ & $-\mathrm{ve}$ & $-\mathrm{ve}$ & $-\mathrm{ve}$ & $-v e$ & $-\mathrm{ve}$ & $-v e$ \\
\hline 2 & Libberman \& Burchard's Test & $-v e$ & $-v e$ & $-\mathrm{ve}$ & $-\mathrm{ve}$ & $-\mathrm{ve}$ & -ve & $-\mathrm{ve}$ & $-v e$ \\
\hline
\end{tabular}

Table 1: The results showing of various tests performed for detection of secondary metabolites in different crude extracts isolated from in-Vitro cultured plant and plant parts.

\begin{tabular}{|c|c|c|c|c|c|c|c|c|}
\hline \multirow{2}{*}{$\begin{array}{l}\text { Secondary } \\
\text { Metabolite }\end{array}$} & \multicolumn{8}{|c|}{ Result } \\
\hline & $\begin{array}{c}\text { Mature } \\
\text { seeds } \\
\text { (S1) }\end{array}$ & $\begin{array}{c}\text { Immature } \\
\text { Seeds } \\
\text { (S2) }\end{array}$ & $\begin{array}{l}\text { Dried } \\
\text { Seeds } \\
\text { (S3) }\end{array}$ & $\begin{array}{c}\text { Apical } \\
\text { Tissues } \\
\text { (P1) }\end{array}$ & $\begin{array}{c}\text { Meristamatic } \\
\text { cells } \\
(\mathbf{P 2}) \\
\end{array}$ & $\begin{array}{c}\text { Whole } \\
\text { Plant } \\
\text { (P3) }\end{array}$ & $\begin{array}{c}\text { Callus } \\
(\mathbf{P 4})\end{array}$ & $\begin{array}{c}\text { Seedling } \\
\text { Plants } \\
\text { (P5) } \\
\end{array}$ \\
\hline Alkaloid & Present & Present & Absent & Absent & Absent & Absent & Absent & Absent \\
\hline Carbohydrate & Present & Absent & Absent & Absent & Absent & Absent & Present & Absent \\
\hline $\begin{array}{l}\text { Reducing } \\
\text { Sugar }\end{array}$ & Absent & Absent & Absent & Absent & Absent & Absent & Absent & Absent \\
\hline Flavonoids & Absent & Present & Absent & Present & Present & Present & Absent & Absent \\
\hline Glycoside & Absent & Absent & Absent & Absent & Absent & Absent & Absent & Absent \\
\hline $\begin{array}{l}\text { Tannins and } \\
\text { Phenolic } \\
\text { compounds }\end{array}$ & Absent & Present & Absent & Present & Present & Present & Present & Absent \\
\hline Saponins & Absent & Absent & Present & Present & Absent & Absent & Absent & Present \\
\hline $\begin{array}{l}\text { Triterpenoids } \\
\text { and Steroids }\end{array}$ & Absent & Absent & Absent & Absent & Absent & Absent & Absent & Absent \\
\hline
\end{tabular}

Table 2: The results summarizing the presence /absence of various metabolites in different crude extracts mined from in-Vitro cultured plant and plant parts.

\section{Reference:}

Hill AF. 1952. Economic Botany. A Textbook of useful Plant Products. 2nd edn. McGraw - Hill Book Company Inc, New York. p. 432

Neeti Dhaka. 2013. A review on tissue culture studies in Eclipta alba - An important medicinal plant. Int. J. Pharm. Sci. Rev. Res., 22(2), 269-275

Kokate C.K., Purohit A.P., and Gokhale S.B. 2006. Pharmacognosy; 23 ed., Nirali prakashan: 493497

Lunaveth V., Mamidala E. 2013. Preliminary phytochemical screening and antibacterial studies of the leaves of Eclipta elba (L). Int J Pharm Bio Sci., 4(3): 380 - 384

Thenmozhi M., Bhavya P.K., Shivaraj R. 2011. Compound identification using HPLC and FTIR in Eclipta alba and Emilia sonchifolia. International Journal of Engineering Science and Technology. 3: $292-298$. 